\title{
Kerekayasaan Informasi Dalam Proses Bisnis
}

\author{
Diana Effendi \\ Program Studi Manajemen Informatika, Universitas Komputer Indonesia, Indonesia \\ diana.effendi@email.unikom.ac.id
}

Diterima 23 Mei 2016

Disetujui 20 Juni 2016

\begin{abstract}
Business process is a series of steps or actions to achieve a certain goal. It can be completed not only in parallel but also separately, by a person or a system. both inside and outside the organization. An enterprise needs an accurate, relevant, and just-in-time information to be operated well. That's why information engineering is needed. Information engineering is an application of a set of related formal techniques for planning, analysis, design, and information system construction in the whole enterprise. This paper aims to summarize this idea comprehensively according to literature review.
\end{abstract}

Index Terms - information engineering, business process, enterprise information system.

\section{Pendahuluan}

Banyak aktivitas manusia yang berhubungan dengan sistem informasi. Tak hanya di negaranegara maju, di Indonesia pun sistem informasi telah banyak diterapkan dimana-mana, seperti di kantor, pasar swalayan, bandara, dan bahkan di rumah ketika pemakai bercengkerama dengan dunia internet. Dari kenyataan tersebut dapat dikatakan peran Sistem Informasi (SI) sangat besar dalam menentukan keberhasilan suatu usaha atau proses bisnis dimana sistem informasi merupakan salah satu senjata untuk meningkatkan daya saing (competitive advantage) perusahaan.

Sebuah proses bisnis dimulai dengan suatu aktivitas (event) yang memicu serangkaian kejadian yang baru akan berakhir jika telah tercapai aspek terahir dari hasil terakhir (final outcome) yang memuaskan dari sudut pandang orang (stakeholders) yang memicu atau memulai aktivitas tersebut. Proses bisnis merupakan serangkaian langkah atau tindakan dimana orang menggunakan informasi dan sumberdaya lainnya untuk menciptakan nilai untuk pelanggan internal dan eksternal.[1]

Langkah-langkah tersebut berkaitan dengan waktu dan tempat, memiliki awal dan akhir, dan memiliki input serta output.

Dalam sistem informasi, stakeholder adalah orang yang berkepentingan terhadap Sistem Informasi yang berjalan maupun yang baru. Stakeholder dapat bersifat teknis maupun nonteknis. Untuk Sistem Informasi, stakeholder dapat diklasifikasikan atas:[2,3]

1. Pemilik sistem (owners)

2. Pengguna sistem (users)

3. Analis sistem (analysts)

4. Perancang sistem (designers)

5. Pembangun sistem (builders)

6. Vendor dan konsultan IT

Terkait proses bisnis yang merupakan serangkaian langkah atau tindakan yang dilakukan untuk mencapai tujuan tertentu, yang dapat dilengkapi baik secara pararel maupun terpisah, oleh orang ataupun sistem, baik di dalam maupun diluar organisasi, maka dibutuhkan informasi. Informasi merupakan salah satu sumber daya penting dalam suatu organisasi; digunakan sebagai bahan pengambilan keputusan. Sehubungan dengan hal tersebut, informasi haruslah berkualitas. Menurut Burch dan Grudnitski (1989), kualitas informasi ditentukan oleh tiga faktor, yaitu: [2],[3],[4],[5]

1. Relevansi

2. Tepat waktu

3. Akurasi

Akurasi berarti bahwa informasi bebas dari kesalahan. Relevansi berarti bahwa informasi benar-benar berguna bagi suatu tindakan keputusan yang dilakukan oleh seseorang. Tepat waktu berarti bahwa informasi datang pada saat dibutuhkan sehingga bermanfaat untuk pengambilan keputusan. [2],[3],[4],[5]

Tujuan dari suatu enterprise untuk memberikan 
pelayanan yang memuaskan bagi pelanggannya akan tercapai salah satunya dengan adanya dukungan pengembangan teknologi informasi dan pengembangan enterprise tersebut. Untuk tujuan inilah kerekyasaan informasi dilakukan oleh suatu enterprise dan dilakukan Information System Planning terlebih dahulu.

II. Mengapa diperlukan information system planning dalam perencanaan sistem informasi

Perencanaan sistem informasi (Information System Planning) dimaksudkan untuk mempersiapkan rencana yang akan menentukan analisis, desain, dan pembangunan sistem yang terkomputerisasi. [2] [3]

Proyek Information System Planning (ISP) menyediakan framework untuk komunikasi tentang hal-hal yang relevan terhadap keputusan perencanaan Sistem Informasi. Tahap ISP memberikan hasil yang mendukung komunikasi perencanaan yang menyangkut enterprise.

Pendekatan ISP adalah filosofi yang umum dalam perencanaan informasi. ISP menyediakan toolkit of tasks, teknik and kemampuan pengiriman untuk membantu dalam merencanakan perencanaan strategi informasi untuk organisasi. ISP menjembatani perbedaan antara Business Strategy Plan (BSP) dan pengembangan IS dengan identifikasi strategi untuk memenuhi kebutuhan informasi pada organisasi secara keseluruhan yang mendukung tujuan bisnis. ISP harus mencerminkan strategi dan kebijakan yang diidentifikasikan dalam BSP. [2][3]

Level yang bervariasi untuk detail arsitektur TI:

1. Chip

2. Program

3. Aplikasi

4. Kumpulan aplikasi terintegrasi

5. Divisi

6. Enterprise

7. Perluasan enterprise

8. Industri

Salah satu tujuan dari perancangan arsitektur sistem informasi adalah untuk menjawab pertanyaan-pertanyaan berikut ini:

1. Bagaimana caranya menguraikan fungsi- fungsi organisasi yang kompleks menjadi sekumpulan fungsi-fungsi yang sederhana?

2. Apa yang membedakan antara proses yang menjadi elemen sistem informasi dengan proses-proses lain di dalam organisasi?

3. Bagaimana keterkaitan antara proses-proses dalam sistem informasi dengan proses-proses dalam sistem organisasi?

4. Bagaimana cara memvalidasi proses pengolahan data dalam organisasi?

\section{KEREKAYASAAN \\ INFORMASI} (INFORMATION ENGINEERING)

Menurut James Matin (1989) definisi Information Engineering adalah the application of an interlocking set of formal techniques for the planning, analysis, design, and construction of information systems on the enterprise wide basis or across a major sector of the enterprise. [6]

Information Engineering (IE) dapat dikatakan merupakan aplikasi sekumpulan teknik formal yang saling berkaitan untuk perencanaan, analisis, desain, dan konstruksi SI di keseluruhan enterprise atau meliputi sektor utama dari enterprise.

Karakteristik dari IE :

1. IE menerapkan teknik terstruktur pada basis enterprise, atau pada sektor utama pada enterprise, bukannya pada basis proyek.

2. IE berlangsung secara top down menempuh tahap-tahap: [6],[7]
a.
Enterprise strategic systems planning
b. Enterprise information
c. Business Area analysis
d. System Design
e. Construction
$f$. Cutover

3. Sejalan dengan tahap-tahap di atas, IE membangun repository (encyclopedia) yang berkembang dengan mantap yang berisi knowledge dalam enterprise, model data, model proses, dan desain sistem.

4. IE membuat framework untuk membangun enterprise yang terkomputerisasi.

5. Sistem yang dibangun terpisah cocok dengan

\section{ULTIMA InfoSys, Vol. VII, No. 1 | Juni 2016}


framework ini.

6. Dalam framework, sistem dapat dibangun dan diubah dengan cepat menggunakan automated tool

7. Pendekatan level enterprise memungkinkan untuk mendapatkan koordinasi sistemsistem yang dibangun secara terpisah, dan memudahkan penggunaan maksimum dari desain dan code yang reusable

8. IE membuat end users berpartisipasi penuh pada tiap level di atas

9. IE membantu evolusi sistem jangka panjang

10.IE mengenalkan bagaimana komputasi dapat sangat membantu tujuan strategis enterprise.

Dua tujuan dasar IE, yaitu :

1. Untuk membangun sistem terintegrasi yang mendukung kebutuhan nyata dari bisnis yang digariskan tujuan dan strategi bisnis.

2. Untuk menyerahkan SI yang memenuhi kebutuhan bisnis pada saat penyerahan yang seharusnya namun dalam framework yang memungkinkan fleksibilitas untuk perubahan di masa mendatang

Hal yang fundamental terhadap filosofi IE adalah penegasan bahwa data dari berbagai Sistem Informasi adalah bersifat terpusat.

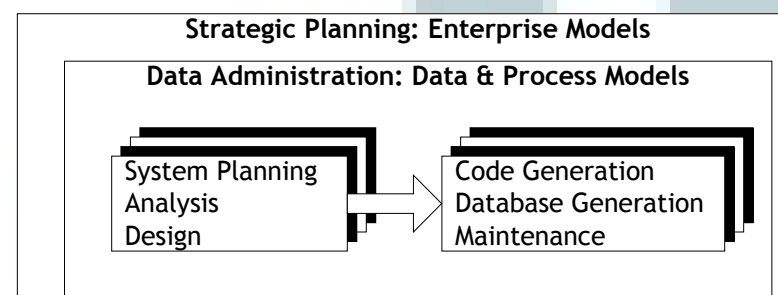

Gambar 1. Framework Enterprise [6]

Fitur penting dari metode IE:

1.Orientasi bisnis: model dari bisnis, yang mendukung tujuan, strategi, kebutuhan manajemen informasi bisnis, yang kesemuanya merupakan dasar dari sistem yang dibangun.

2.Pendekatan arsitektural: sesuai pendekatan top-down, metode IE pada tahap awal membuat "arsitektur" (atau model) dari level bisnis yang berbeda dan data di dalamnya. Hasilnya adalah pandangan organisasional terhadap kebutuhan data dan informasi serta aktivitas bisnis. Penggunaan arsitektur ini adalah untuk identifikasi di mana pengembangan SI dibutuhkan dan struktur data yang diperlukan untuk memenuhi kebutuhan ini.

Sedangkan framework dari IE, sebagai berikut

1. Metode IE bersifat top-down yang diawali dengan tinjauan secara luas oleh top management terhadap enterprise secara keseluruhan. IE memungkinkan pengadopsian pendekatan strategis.

2. Sejalan dengan pelaksanaan metodologi, pandangan yang lebih detail terus dihasilkan. Tujuan dan fokus berubah seiring pelaksanaan metodologi: tiap tahap memiliki tujuan berbeda namun tujuan keseluruhan tetap konsisten.

Varian dari framework IE terdapat untuk lingkungan pengembangan yang berbeda seperti: RAD, Package Evaluation, Re-engineering, dan lain-lain.

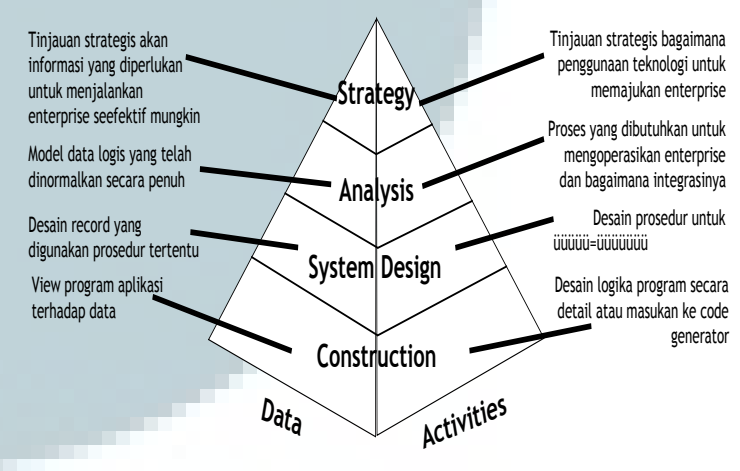

Gambar 2. Piramida Sistem Informasi [6]

III. 1 Tahapan-tahapan IE

a. Information Strategy Planning

Information Strategy System bertujuan untuk mengkonstruksi arsitektur informasi dan strategi yang mendukung tujuan dan kebutuhan organisasi secara menyeluruh, menyangkut tujuan strategis, sasaran top management dan critical success factor, serta bagaimana penggunaan teknologi untuk menciptakan peluang baru dan meningkatkan daya saing. Tinjauan tingkat enterprise terhadap fungsi, data, dan kebutuhan informasi mengandung identifikasi area bisnis yang relevan.

Information Strategy Planning dimaksudkan untuk mempersiapkan rencana yang akan menentukan analisis, desain, dan pembangunan sistem terkomputerisasi. 
Proyek ISP menyediakan framework untuk komunikasi tentang hal-hal yang relevan terhadap keputusan perencanaan SI. Tahap ISP memberikan hasil yang mendukung komunikasi perencanaan yang menyangkut enterprise.

Tujuan ISP antara lain:

1. Menyusun strategi informasi yang berbasis pada evaluasi strategi bisnis

2. Menyusun rencana pengembangan dari sistem berorientasi pemakai untuk memenuhi kebutuhan informasi dan prioritas enterprise

3. Identifikasi data sebagai sumber daya korporat dan menyusun dasar untuk analisis dan pengawasannya.

4. Menetapkan arsitektur informasi untuk pengembangan yang akan datang dari sistem yang berbagi pakai data secara kompatibel

5. Evaluasi efektifitas dari sistem berjalan, dan menentukan langkah migrasi ke arsitektur sistem target.

6. Menyusun strategi teknis untuk penggunaan IT baru yang terbaik.

7. Melibatkan manajemen pengguna dalam pengembangan sistem.

8. Mendefinisikan organisasi fungsi manajemen informasi yang paling efektif dalam enterprise.

9. Membuat perkiraan dampak penggunaan IT yang efektif terhadap misi enterprise secara keseluruhan.

10.Meningkatkan kesadaran manajemen akan pengembangan dalam dan kesempatan dari IT.

Terdapat lima tugas utama dari ISP, sebagai berikut :

1. Merencanakan dan mengaktifkan ISP. Tujuannya adalah mendefinisikan ruang lingkup, sumber daya tim, dan jadwal kerja dari proyek

2. Uraikan kebutuhan. Tujuannya adalah menghasilkan pandangan yang meluas terhadap organisasi dengan menganalisis Business Strategy Plan juga mempertimbangkan dampak dari IT pada strategi

3. Analisis lingkungan Saat ini. Tujuannya adalah mempertimbangkan seberapa baik SI berjalan memenuhi kebutuhan organisasi. Undertake an inventory of current systems and data stores; consider the current technical environment in relation to the above.

4. Mendefinisikan arsitektur. Tugas pokok dari ISP adalah membangun framework arsitektural untuk pengembangan SI di masa mendatang untuk memenuhi kebutuhan organisasi akan informasi.

a. Arsitektur Sistem Bisnis-menunjukkan sistem bisnis yang mungkin dan data store yang dibutuhkan untuk mendukung Information Architecture

b. Arsitektur Teknis - mendeskripsikan secara luas hardware, software, dan lingkungan komunikasi yang dibutuhkan untuk mendukung Business System Architecture.

5. Menefinisikan strategi dan rencana. Strategi alternatif untuk mengimplementasikan SI yang diidentifikasikan, dievaluasi untuk memungkinkan perencanaan proyek yang berikutnya, seperti: Business Area Analysis Projects, RAD projects, User Computing Projects.

b. Business Area Analysis

Business Area Analysis bertujuan untuk memahami area bisnis individual dan menetapkan kebutuhan sistemnya, menyangkut proses apa yang dibutuhkan untuk menjalankan area bisnis yang dipilih, bagaimana keterhubungan proses, dan data apa yang diperlukan.

Business Area Analysis merupakan area bisnis yang diidentifikasikan dalam ISP ditinjau secara individual dan analisis fungsi dan data detil dilakukan. Keterlibatan maksimum endusers diperlukan.

Tugas dalam Business Area Analysis, yaitu :

1. Entity and Function Analysis - meliputi analisis entitas dan relationship, proses dan ketergantungan, kontruksi diagram untuk menyajikannya. Gunakan Entity Relationship Diagram sebagai dasar penyajian.

2. Interaction Analysis - uji relationship dan interaksi antara data dan fungsi. Bisa memakai matriks function/entity

3. Current Systems Analysis - modelkan sistem berjalan. Kumpulkan data dari semua sumber saat ini (contoh: input screen) dan verfikasi

4. Confirmation - cek silang hasil dari analisis sebelumnya dalam hal kelengkapan, kebenaran, dan stabilitas

5. Planning for Design - definisikan area 
desain (area yang akan dibangun), pertimbangkan faktor implementasi/ transisi

c. System Planning and Design

System planning and design bertujuan untuk menetapkan kelakuan system seperti yang diinginkan pengguna dan dapat dicapai dengan teknologi yang tersedia, menyangkut bagaimana proses yang dipilih dalam bisnis diterapkan dalam prosedur dan bagaimana prosedur ini bekerja. Desain prosedur ini memerlukan keterlibatan end-user.

System Planning and Design, merupakan :

1. Tahapan yang berhubungan dengan hal teknis. Dibagi menjadi desain sistem bisnis dan desain teknis. Desain sistem bisnis sama dengan desain logis dari pengembangan aplikasi yang diajukan. Pengumpulan fakta digunakan untuk merancang sistem untuk memenuhi kebutuhan bisnis yang teridentfikasi.

2. Aspek terkomputerisasi dari desain sistem bisnis kemudian dirancang ke level teknis sehingga konstruksi final dan operasi dari sistem dapat direncanakan dan dibiayai

3. Keluaran dari tahap ini adalah spesifikasi teknis, mencakup lingkungan hardware dan software, penggunaanna, konvensi dan standar.

d. Construction and cutover

Construction and cutover bertujuan untuk membangun dan mengimplementasikan sistem yang dikehendaki dari tiga tahap sebelumnya (Implementasi prosedur). Desain dihubungkan ke tahap ini melalui prototyping. Construction and Cutover mencakup tahapan konstruksi, cutover, dan produksi. Terdiri dari beberapa tugas seperti: system generation, system verification, persiapan peralihan, instalasi software baru, penerimaan akhir, system development lebih lanjut.

\section{SIMPULAN}

Kerekayasaan Informasi merupakan aplikasi kesatuan teknik formal untuk perencanaan, analisis, desain dan konstruksi sistem informasi pada enterprise secara menyeluruh atau diantara sejumlah sektor enterprise.

Untuk melakukan kerekayasaan informasi dalam proses bisnis suatu sistem informasi dilakukan melalui 4 tahapan yaitu Information Strategy Planning , Business Area Analysis,
System Planning and Design, Construction and cutover.

\section{DAFTAR PUSTAKA}

[1] Surendro,K. Pemanfaatan Enterprise Architecture Planning Untuk Perencanaan Strategis Induk Sistem Informasi, JurnalTeknik Informatika, 2009, vol.8, No. 1.

[2] Alter, Steven. Information Systems: Foundation of E-business. Prentice Hall. New Jersey. 2002.

[3] Alter, Steven. Information Systems: A Management Perspective. $3^{\text {rd }}$ edition, Addison Wesley Longman, 1999.

[4] Burtlon, Roger, T. Business Process Management : Profiting from Process, USA: Sams Publishing, 2001.

[5] Jogiyanto HM. Analisis dan Desain Sistem Informasi : Pendekatan Terstruktur Teori dan Praktek Aplikasi Bisnis, Yogyakarta:Andi Offset, 2001.

[6] Martin, James. An Introduction Information Engineering : From Strategic Planning to Information Sysytem. Addison-Wesley Longman Publishing . Boston. 1990.

[7] Aradea, Supriana I, Surendro K, Konsepsi Data dan Informasi Sebagai Penyedia Layanan Pengetahuan, Konferensi Nasional Sistem Informasi (KNSI) Univ Klabat - Institute Teknologi Bandung, 2015. 